Plant M. Drugs in perspective. London: Hodder and Stoughton, 1987

5 Murry R. The medical profession. In: Plant M, Hore B, eds. Alcohol problems in employment. London: Croom Helm, 1980

6 Paget J. What becomes of medical students? Saint Bartholomew's Hospital Reports $1869 ; 5: 238-42$.

7 Wallace $\mathrm{P}$, Haines A. General practitioner and health promotion. Br Med $\mathcal{F}$ 1984;289:534-6.

8 Wallace $\mathrm{P}$, Haines $\mathrm{A}$. Use of a questionnaire in general practice to increase the recognition of patients with excessive alcohol consumption. $\mathrm{Br}$. Med $\mathrm{f}$ 1985;290:1949-53.

9 Wallace P, Brennan P, Haines A. Drinking patterns in general practice patients. F R Coll Gen Pract 1987;37:354-7.

10 Anonymous. That's the limit. London: Health Education Authority, 1988:5.

11 Mayfield D, McLeod G, Hall P. The CAGE questionnaire: validation of a new screening instrument. Am $\mathcal{P}$ Psychiatry 1974;131:1121-3.
2 Anderson P, Cremona A, Wallace P. What are safe levels of alcoho consumption? BrMed f 1984;289:1657-8

13 Goddard I, Ikin C. Drinking in England and Wales in 1987. London: HMSO, 1988.

14 Breeze E. Women and drinking. London: HMSO, 1985.

15 Office of Population Censuses and Surveys. General household survey 1984 London: HMSO, 1986.

16 Royal College of Physicians. A great and growing evil. London: Tavistock, 1987.

17 Wald N, Kiryluk S, Darby S, Doll R, Pike M, Peto R. United Kingdom smokin statistics. Oxford: Oxford University Press, 1987.

18 Office of Population Censuses and Surveys. Cigarette smoking 1972 to 1986. OPCS monitor 1988; 1 (SS88/1.)

licipted 12 April 1989$)$
Department of Human Molecular Genetics, Central Institute of Molecular Biology, Academy of Sciences of the German Democratic Republic, 1115 Berlin-Buch, German Democratic Republic Charles Coutelle, $\mathrm{MD}$, professor of human molecular genetics

\section{Department of}

Biochemistry and

Molecular Genetics and North West Thames

Regional DNA Laboratory, St Mary's Hospital Medical School, London W2 1PG

Carolyn Williams, BSC, senior biochemist

Robert Williamson, PHD, professor of biochemistry

Institute of Obstetrics and Gynaecology, Royal Postgraduate Medical School, London W12 0HS Alan Handyside, PHD, senior lecturer

Kate Hardy, MA, research assistant

Robert Winston, FRCOG, professor of fertility studies

Correspondence to: Professor R Williamson, St Mary's Hospital Medical School, London W2 1PG.

\title{
Genetic analysis of DNA from single human oocytes: a model for preimplantation diagnosis of cystic fibrosis
}

\author{
Charles Coutelle, Carolyn Williams, Alan Handyside, Kate Hardy, Robert Winston, \\ Robert Williamson
}

\begin{abstract}
Gene sequences in human oocytes were studied to investigate the possibility of diagnosing inherited or sporadic genetic disease before implantation after in vitro fertilisation. By specific amplification the possibility of analysing the DNA from single human oocytes for a specific gene was shown, and genotypes for markers closely linked to cystic fibrosis and Duchenne muscular dystrophy were determined. Single oocytes were used to approvimate the total amount of DNA present in a single cell taken for biopsy from a 4-16 cell blastocyst. With a new technique for specific DNA amplification, the polymerase chain reaction, these data can be obtained within several hours of cell isolation. Extreme care must be taken to avoid any contamination of the sample with DNA from other sources.

With this technique genotyping for single gene disorders is feasible with an accuracy and on a time scale that would allow implantation of the zygote after in vitro fertilisation without freezing.
\end{abstract}

\section{Introduction}

Prenatal diagnosis of genetic abnormalities by analysing DNA can now be offered for inherited diseases that are caused by a known gene defect, provided that DNA probes are available to identify the mutated gene or detect a restriction fragment length polymorphism closely linked to the affected locus. ${ }^{1}$ New techniques that use luteinising hormone releasing hormone agonists to obtain large numbers of oocytes, progress in techniques of in vitro fertilisation, and the successful development of fertilised embryos in vitro to healthy children have led to requests for diagnosis from DNA before implantation of the fertilised egg from families known to be at risk for genetic disease. ${ }^{3+}$ This is possible for repetitive DNA sequences, such as those on the $\mathrm{Y}$ chromosome that permit sex testing before implantation. ${ }^{5}$ In this study we show that similar analysis will be possible for single genes, such as the cystic fibrosis gene.

There is a particular demand for such diagnostic facilities from women who were sterilised after the birth of an affected child but who now wish to have more children. Such a diagnosis would have to be made on a single blastomere or on only a very few embryonic cells taken at an early stage of development, and preferably be quick enough to allow the pre-embryo to be transferred without cryopreservation. Until recently the sensitivity of detecting single copy sequences in the human genome was not sufficient to permit gene analysis with DNA from a single cell, but now the polymerase chain reaction can be used to amplify specific DNA sequences. ${ }^{5-7}$

Two common inherited diseases are cystic fibrosis and Duchenne muscular dystrophy. We used gene amplification with oligonucleotide primers specific for a part of the coding sequence of dystrophin, which when mutated causes Duchenne muscular dystrophy, and with primers identifying the locus CS.7, which maps close to the mutation that causes cystic fibrosis.

\section{Materials and methods}

DNA was obtained from oocytes collected from women undergoing in vitro fertilisation ${ }^{8}$; the oocytes studied had failed to fertilise after insemination. Unfertilised oocytes were used because they are similar to single blastomeres cytologically, contain only the maternal genome, and are diploid. Contamination with adherent cumulus cells or spermatozoa was avoided by removing the zonae pellucidae. Each oocyte was examined for evidence of the first polar body, which in most cases was lost when the oocytes were pipetted. Each oocyte was transferred into a screwcapped siliconised Eppendorf tube and boiled with $20 \mu \mathrm{l}$ water for five minutes before the polymerase chain reaction cocktail was added.

Polymerase chain reaction entails enzymatic copying of DNA using a series of repeated cycles, in each of which the DNA between two oligonucleotide primers is synthesised, so as to give logarithmic amplification of the gene sequence under study. ${ }^{5-7}$ The amplification of DNA was performed in $100 \mu \mathrm{l}$ assay volumes, each containing $1 \cdot 5-2 \cdot 0$ units of Taq DNA polymerase (Cetus/Perkin-Elmer) as outlined in the manufacturer's recommendations. ${ }^{6}$ The $\mathrm{mix}$ contained $50 \mathrm{mM}$ potassium chloride, $10 \mathrm{mM}$ TRIS-chloride at $\mathrm{pH} 8 \cdot 3$, $1.5 \mathrm{mM}$ magnesium chloride, $0.01 \%$ (wt/vol) gelatin, and $200 \mu \mathrm{M}$ of each deoxynucleotide triphosphate.

To analyse the gene for Duchenne muscular dystrophy we used 50 pmol of the oligonucleotide primers of 20 bases $5^{\prime}$-GAAATTGATCGGGAATTGCA-3' and 5'-AATTTGTGCAAAGTTGAGTC-3' bordering a 183 base pair exon of the dystrophin gene locus (nucleotides 5948 to 6130). ${ }^{9}$ To analyse the gene for cystic fibrosis we used the oligonucleotide primers of 20 bases $5^{\prime}$-ATTTACAAGTCCTAGCTCTT- $3^{\prime}$ and 5'-AAATGATGGCAAGAGATGTC-3' bordering a 324 base pair sequence containing the polymorphic Hhal restriction site in linkage disequilibrium with cystic fibrosis. ${ }^{10}$ In all experiments that used less than $500 \mathrm{ng}$ of DNA template, and for all oocyte 


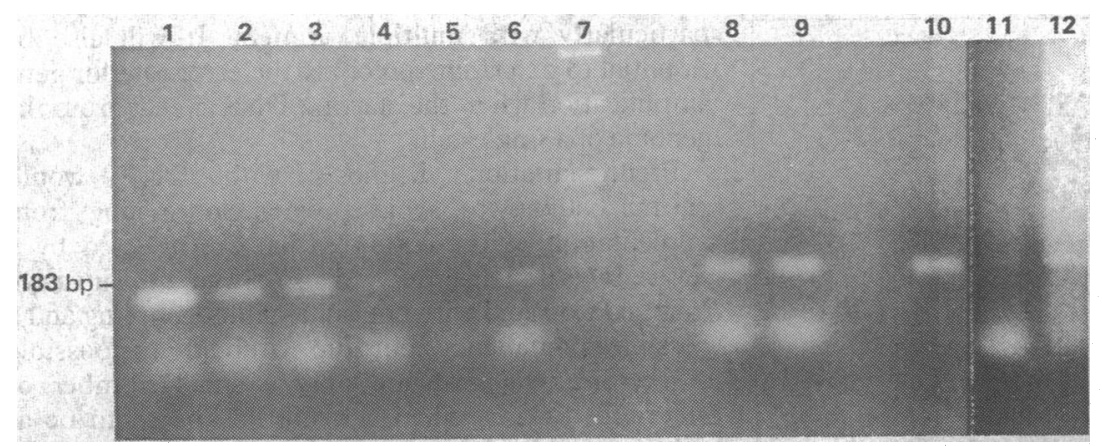

FIG 1-Polymerase chain reaction products using Duchenne muscular dystrophy oligonucleotide primers for dilution series of human DNA (lanes 1-6) and of five (lane 8), 14 (lane 9), and one oocyte (lanes 11 and 12). A $1 \mathrm{~kb}$ ladder (lane 7) and polymerase chain reaction product from the original dystrophin cDNA clone

(lane 10) were used as markers

In all experiments, once the reaction cocktail containing all necessary ingredients with the exception of the Taq polymerase enzyme had been prepared the tubes were heat denatured for six minutes at $100^{\circ} \mathrm{C}$. The enzyme was then added and the appropriate cycling regimen begun. For the Duchenne muscular experiments, siliconised Eppendorf tubes and tips were used. dystrophy primers the cycling regimen was one minute at $93-95^{\circ} \mathrm{C}$, two minutes at $50^{\circ} \mathrm{C}$, and two minutes at $68-72^{\circ} \mathrm{C}$. For the cystic fibrosis primers the cycling regimen was one and a half minutes' denaturation at $96^{\circ} \mathrm{C}$, two minutes' annealing at $61.5^{\circ} \mathrm{C}$, and one and a half minutes' extension at $70^{\circ} \mathrm{C}$.

When reactions were carried out with a thermal cycler (Cambio, Cambridge) cycling times were modified slightly so as to obtain as specific a product as possible. After 40 cycles the reaction was completed by a final 10 minute extension step. In some experiments $5 \mu \mathrm{l}$ of this reaction mixture was carried through a second round of amplification with a similar cycling regimen but with a lower annealing temperature of $60 \cdot 5^{\circ} \mathrm{C}$.

\section{Results}

To test the sensitivity of gene amplification for single copy genes, a serial dilution of DNA from a normal adult was amplified for 40 cycles using the oligonucleotides specific for the Duchenne muscular dystrophy gene. Figure 1 shows the amplification for samples containing from $50 \mathrm{ng}$ (lane 1) to $1 \mathrm{pg}$ (lane 6) DNA. For the dilution at which the amount of DNA amplified ( $5 \mathrm{pg}$ or $1 \mathrm{pg}$ ) is of the order of $6 \mathrm{pg}$, which is approximately the amount present in a single diploid cell, the chance of having a single copy of any specific gene in the DNA under test becomes $<1.0$; therefore, a positive amplification at $1 \mathrm{pg}$ with no product at $5 \mathrm{pg}$ is not unexpected. Lanes 8 and 9 show the reaction products after amplification of two samples of pooled unfertilised human oocytes containing five (lane 8) and 14 (lane 9) cells. The amplified products obtained from single oocytes, with $70 \mu \mathrm{l}$ of the $100 \mu \mathrm{l}$ reaction product loaded on to a $2 \%$ agarose gel and stained with ethidium bromide, are shown in lanes 11 and 12.

To verify the identity of the amplified gene products from single oocytes, $5 \mu \mathrm{l}$ of the $100 \mu \mathrm{l}$ initial reaction mix was used as starting material and amplified a second time for a further 40 cycles. A TaqI restriction site was detected 24 base pairs from one end, as predicted from the complementary DNA sequence (fig 2).

Figure 3 shows similar data for the sequence in linkage disequilibrium with cystic fibrosis. Amplification was obtained with a dilution series of genomic DNA ( $50 \mathrm{ng}$ to $5 \mathrm{pg}$ ) and for two samples of DNA from single human oocytes obtained from the same woman. Optimisation of the amplification conditions was easier with an automated heating block (Cambio, Cambridge) rather than moving samples manually between water baths; reproducibility to $1^{\circ} \mathrm{C}$ is required for the CS.7 primers, which are sensitive to small changes in the conditions for amplification.

After the initial round of 40 cycles only very faint bands could be detected. Amplification could, however, be shown easily by taking $5 \mu \mathrm{l}$ of the first round amplification product through a further 40 cycles at an annealing temperature just $1^{\circ} \mathrm{C}$ lower than formerly. A slight smear in the product from one of the oocytes (lane 5) and the weak additional bands show how sensitive the system is to variations in conditions at these very low template concentrations; they probably represent non-specific amplification.

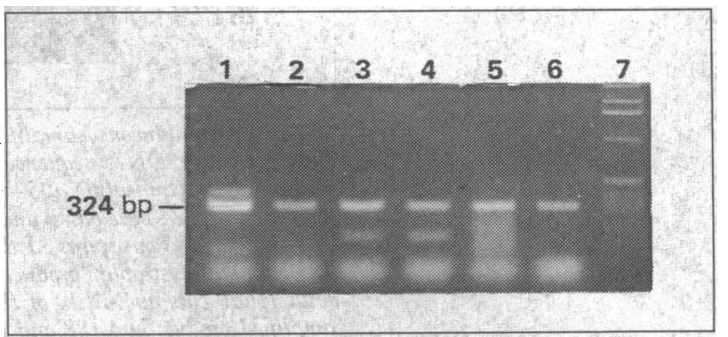

FIG 3-Polymerase chain reaction products using cystic fibrosis oligonucleotide primers. Amounts of DNA per well in lanes 1 to 4 were $50 \mathrm{ng}, 50 \mathrm{pg}, 10 \mathrm{pg}$, and $5 \mathrm{pg}$. Lanes 5 and 6 show the amplification products of one oocyte each; lane 7 is a 1 kb ladder used as marker

Figure 4 shows that Ban II cleaves the amplified DNA corresponding to CS.7 from a single oocyte (lanes 1 and 6) as expected from the nucleotide sequence. ${ }^{11}$ Digestion of the same products by HhaI gives DNA fragments corresponding to homozygosity for the polymorphic cleavage site $(2 / 2)$ for one oocyte (lane 2 ), and heterozygosity (1/2) for this site in the other (lane 7). This is consistent with the maternal (1/2) genotype. Experiments with blank tubes did not show amplification for these sequences.

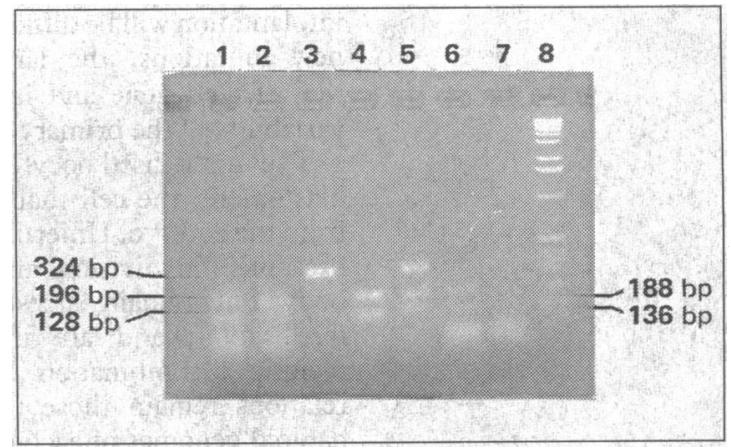

FIG 4-BanII and HhaI restriction analysis of the CS. 7 product of the single oocyte reactions shown in figure 3 (lanes 1,2 and 6,7$)$ together with control amplification product obtained with genomic DNA from a known heterozygote for the $H$ haI site (lanes $3,4,5$ ). Restriction with BanII (lanes 1, 4, and 6) cuts the 324 base pair product into 196 and 128 base pair bands, proving the identity of the amplified product. Hhal restricts one allele of the heterozygote product (lane 5) into 188 and 136 base pair fragments; the other allele remains unrestricted. Both oocyte amplified products show the HhaI restriction pattern (lanes 2 and 7), but the non-restricted product is also present in lane 7. Lane 3 shows the unrestricted control amplified product and lane $8 a$ $1 \mathrm{~kb}$ ladder

To investigate recombination and to test for several inherited diseases simultaneously it would be useful to coamplify several different pairs of oligonucleotides in the same tube with the same template DNA. Figure 5 shows that coamplification of a selected region of the dystrophin gene and the sequence recognised by CS.7 is possible in genomic DNA.

\section{Discussion}

Duchenne muscular dystrophy and cystic fibrosis are two of the most common severe single gene defects 


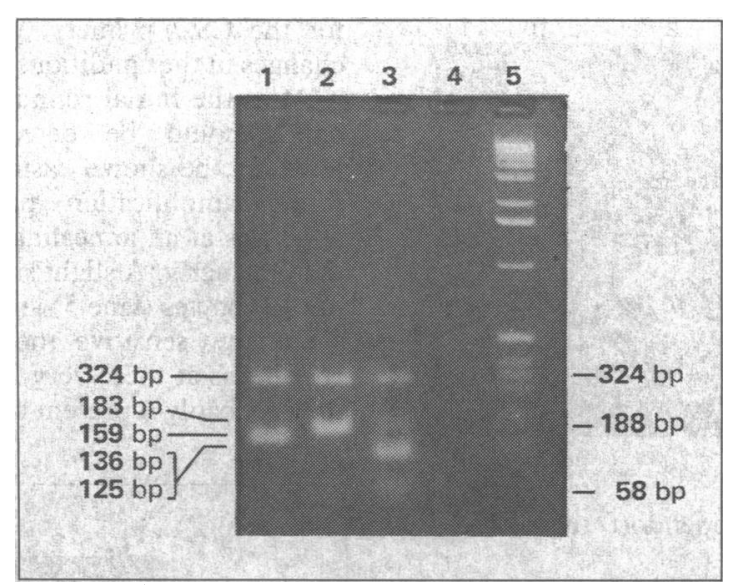

FIG 5-Simultaneous amplification of CS.7 and dystrophin complementary DNA sequences from genomic DNA in a single reaction assay (annealing at $52^{\circ} \mathrm{C}$ ). Lane 2: CS.7 amplified product (upper band, 324 base pairs) and dystrophin cDNA amplified product (lower band, 183 base pairs). Lane 1: restriction with TaqI reduces the 183 base pair dystrophin product to 159 base pairs. Lane 3: restriction with Hhal cuts one allele of the heterozygote 324 base pair CS.7 amplified product into 188 and 136 base pair bands. The dystrophin cDNA product is also cut by this enzyme to give 125 and 584 base pair fragments

affecting children in our countries. CS. 7 identifies a useful gene marker for antenatal diagnosis of cystic fibrosis. ${ }^{12}{ }^{13}$ It is likely that more than $85 \%$ of cystic fibrosis chromosomes carry the same mutation, ${ }^{10}$ and therefore a single pair of oligonucleotide primers for gene amplification could diagnose many of the fetuses at risk.

The complementary DNA oligonucleotides of dystrophin used in these experiments were chosen from the complementary DNA sequences known to detect deletions in about half of the patients with Duchenne or Becker muscular dystrophy. ${ }^{14}$ Diagnosis of Duchenne or Becker muscular dystrophy before implantation will be difficult because of the high rate of new mutations, the large size and complexity of the affected gene and its messenger RNA, and the variability of the primary defect within the DNA.

The unfertilised oocyte is a good model for a single blastomere, the cell that will be obtained for biopsy from the embryo. Unfertilised oocytes have undergone first meiotic division and extruded the first polar body but remain arrested in metaphase II until fertilisation, and are therefore diploid. Although meiotic recombination has occurred, the linkage relations remain those that were derived from the haploid genomes of each of the mother's parents over long regions of the chromosome, as on average there are only one or two crossovers on each chromosome.

Using this technique it will be possible to establish the paternal and maternal haplotypes of the preembryo as well as the maternal recombinant linkage map. This would require several different oligonucleotide primer pairs recognising linked marker loci and also estimating the positions of crossovers between these during first meiosis of the oocyte.

The discordance seen for the two oocytes from the same woman with CS.7 oligonucleotides (fig 4) is probably due to a meiotic crossover as the donor was heterozygous for the CS.7/HhaI polymorphism. We regard it as very unlikely that the first polar body persists after the removal of the zona pelucida as this structure was clearly visible and great care was taken to remove it.

These experiments were performed with nanogram amounts of template DNA. As precise optimisation (and concern over cross contamination) becomes increasingly important with decreasing amounts of template it may become more important to obtain routine amplification with DNA from a single cell, particularly with multiple primers. It will also be essential to determine precisely the error rate for gene amplification when the starting DNA comes from the genome of a single cell.

Preimplantation diagnosis with DNA would permit couples to avoid pregnancies arising from implantation of pre-embryos that are affected by a severe inherited disorder and also to avoid the invasive trauma associated with chorionic villus sampling and a possible spontaneous abortion. Although it is possible at present to investigate only a small number of inherited diseases when a family is known to be at risk, new procedures for testing of carriers and the availability of new probes should widen the range in the near future.

Using these oligonucleotide primers for DNA amplification with embryonic cells taken for biopsy is possible in principle. For many genetic diseases one or a few defined chromosomal mutations have been identified as causative, or specific restriction fragment length polymorphism haplotypes have been found to be in linkage disequilibrium in most people who have the disease. These analytical procedures will allow rapid development of preimplantation diagnosis with DNA for these conditions, provided that the obstetric and embryological problems of removal of single blastomeres from pre-embryos have been solved. It should be noted, however, that only about a quarter of couples who try to solve fertility problems with in vitro fertilisation have a pregnancy that goes to term, and in vitro fertilisation itself has resource implications both for the families and the clinical services using it.

We thank Richard Penketh (Royal Postgraduate Medical School), Nick Lench (St Mary's), Henry Erlich and colleagues (Cetus), and Alex Markham (ICI Diagnostics) for helpful discussions; Drs Sandra Thomson (Oswel DNA Labs, Edinburgh) and Gottfried Herrmann (Central Institute for Molecular Biology, Berlin-Buch) for providing the primer oligonucleotides; Astrid Speer and Andre Rosenthal (Central Institute of Molecular Biology, Berlin-Buch) and Kay Davies (Nuffield Department of Clinical Medicine, Oxford) for providing dystrophin complementary DNA sequence in advance of publication; and the Wellcome Trust, Cystic Fibrosis Research Trust, and Muscular Dystrophy Group (UK) for generous support.

1 Cooper DN, Schmidtke J. Diagnosis of human genetic disease usin recombinant DNA. Hum Genet 1987;77:66-75.

2 Rutherford AJ, Subak-Sharpe R, Dawson K, Margara RA, Franks S, Winston RML. Improvement of in vitro fertilisation after treatment with buserelin, an agonist of luteinising hormone releasing hormone. $\mathrm{Br} \mathrm{Med} \mathcal{f}$ 1988;296: 1765 .

3 Edwards RG, Hollands P. New advances in human embryology: implication of the preimplantation diagnosis of genetic disease. Hum Reprod 1988;3: $549-56$.

4 Penketh RJA, McLaren A. Prospects for prenatal diagnosis during pre-implantation human development. Baillieres Clin Obstet Gynaecol 1987;1:747-64.

5 Handyside AH, Penketh RJA, Winston RML, Pattinson JK, Delhanty JDA, Tuddenham EGD. Biopsy of human preimplantation embryos and sexing

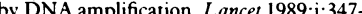

6 Saiki RK, Scharf S, Faloona FA, et al. Enzymatic amplification of $\beta$-globin genomic sequences and restriction site analysis for sickle cell anemia. Science 1985;230:1350-4

7 Li H, Gyllensten UB, Cui X, Saiki RK, Erlich HA, Arnheim N. Amplification and analysis of DNA sequences in single human sperm and diploid cells. Nature 1988;335:414-7.

8 Hillier SG, Dawson KJ, Afnan M, et al. Embryo culture: quality control in clinical in vitro fertilization. In: Thompson W, Joyce DN, Newton JR, eds. Proceedings of the twelfth study group of the Royal College of Obstetricians and Gynaecologists. London: RCOG, 1984:125-40.

9 Koenig M, Monaco AP, Kunkel LM. The complete sequence of dystrophin predicts a rod-shaped cytoskeletal protein. Cell 1988;53:219-28.

10 Estivill X, Farrall M, Scambler P, et al. A candidate for the cystic fibrosis locus isolated by selection for methylation free islands. Nature 1987;326:840-5

11 Wainwright BR, Scambler PJ, Stanier P, et al. Isolation of a human gene with protein sequence similarity to human and murine int- 1 and the drosophila segment polarity mutant wingless. EMBO 7 1988:7:1743-8.

12 Lench N, Stanier P, Williamson R. Simple non-invasive method to obtain DNA for gene analysis. Lancet 1988 ;i: 1356-8.

13 Beaudet A, Feldman GL, Williamson R, O'Brien WE. Prenatal diagnosis of cystic fibrosis by DNA amplification for detection of KM-19 polymorphism. Lancet 1988; ;: 102 .

14 Speer A, Spiegler AWJ, Hanke R, et al. Possibilities and limitations of prenatal diagnosis and carrier determination for Duchenne and Becker muscular dystrophy using cDNA probes. $\mathcal{F}$ Med Gen 1989;26:1-5.

(Accepted 19 May 1989) 